\title{
Neuregulins Increase $\alpha 7$ Nicotinic Acetylcholine Receptors and Enhance Excitatory Synaptic Transmission in GABAergic Interneurons of the Hippocampus
}

\author{
Yun Liu, Byron Ford, Mary Anne Mann, and Gerald D. Fischbach \\ Section on Developmental Neurobiology, National Institute of Mental Health, National Institutes of Health, Bethesda, \\ Maryland 20892
}

\begin{abstract}
Neuregulins are highly expressed in the CNS, especially in cholinergic neurons. We have examined the effect of neuregulin on nicotinic acetylcholine receptors (nAChRs) in neurons dissociated from the rat hippocampus. Rapid application of acetylcholine (ACh) induced a rapidly rising and decaying inward current in some of the neurons, which was completely blocked by methyllycaconitine, a specific antagonist of the $\alpha 7$ subunit of the nAChR. When the cells were treated with 5 nм neuregulin (NRG1- $\beta 1$ ) for 2-4 d, a twofold increase in amplitude of the peak ACh-induced current was observed, and there was a comparable increase in ${ }^{125} \mathrm{I}-\alpha$-bungarotoxin binding. The fast ACh-induced peak current was prominent in large neurons that also contained GABA immunoreactivity. These presumptive
\end{abstract}

ARIA is a $42 \mathrm{kDa}$ glycoprotein purified from chick brain on the basis of its ability to stimulate the synthesis of acetylcholine receptors (AChRs) in cultured chick myotubes (Usdin and Fischbach, 1986; Harris et al., 1988; Falls et al., 1993). It also showed that it is a member of a family of proteins encoded by the neuregulin 1 (NRG1) gene. Other founding members of the family include glial growth factor (Goodearl et al., 1993; Marchionni et al., 1993), neu differentiation factor (NDF; Wen et al., 1992), and heregulin (HRG; Holmes et al., 1992). At present, $\sim 15$ NRG1 isoforms have been identified that differ because of alternative mRNA splicing, alternative promoter use, or both. All members of this family contain an epidermal growth factor-like (EGF-L) domain, and they all activate receptor-tyrosine kinases that are related to the EGF receptor (Carraway and Burden, 1995; Lemke, 1996; Fischbach and Rosen, 1997). In the current nomenclature (Meyer et al., 1997), ARIA (like NDF and heregulin) is a type $1-\beta 1$ isoform of the $N R G 1$ gene. It has an Ig domain N-terminal to the EGF-L domain (type 1), and the EGF-like domain ends in a $\beta 1$ configuration. Three other neuregulin genes have been identified in the past few years (Carraway et al., 1997; Zhang et al., 1997, 1998; Harari et al., 1999).

In all of the original members of the NRG1 family, the 55- to

\footnotetext{
Received Feb. 26, 2001; revised May 11, 2001; accepted May 18, 2001.

We thank David Ide for superb help in design and construction of equipment. Correspondence should be addressed to Dr. Yun Liu, National Institute of Mental Health, National Institutes of Health, 36 Convent Drive, Building 36/1A31, Bethesda, MD 20892. E-mail: liuy@ninds. nih.gov.

B. Ford's present address: Department of Anatomy and Neuroscience, Morehouse School of Medicine, 720 Westview Drive Southwest, Atlanta, GA 30310.

G. D. Fischbach's present address: Office of the Dean, Columbia University, College of Physicians and Surgeons, 630 West 168th Street, New York, NY 10032.

Copyright (C) 2001 Society for Neuroscience $0270-6474 / 01 / 215660-10 \$ 15.00 / 0$
}

GABAergic neurons constituted $\sim 10 \%$ of neurons present in 7to 9-d-old cultures. In addition to the large inward peak current, ACh also evoked transmitter release from presynaptic nerve terminals. Pharmacologic experiments indicated that the shower of PSCs was mediated by glutamate, with a small minority caused by the action of GABA. Chronic exposure to NRG1- $\beta 1$ increased the amplitude of ACh-evoked PSCs but not the minimum "quantal" PSC. NRG1- $\beta 1$ also increased the percentage of neurons that exhibited ACh-evoked PSCs.

Key words: neuregulin; nicotinic acetylcholine receptors; hippocampus; $\alpha$-bungarotoxin; GABAergic interneurons; synaptic transmission

60-amino acid EGF-like region in the extracellular domain is essential for neuregulin binding and for all known NRG1 actions. $\beta$ isoforms are $\sim 1000$ times more potent than are $\alpha$ isoforms on muscle cells, Schwann cells, and neurons. Therefore, in this study, we used the recombinant EGF-like domain of human heregulin $\beta 1\left(\mathrm{HRG}_{217-246}\right.$; Holmes et al., 1992) and will refer to it simply as "NRG1- $\beta 1$ ".

ARIA and perhaps other NRGs play important roles at the vertebrate neuromuscular junction. Heterozygous mice in which Ig-containing NRG isoforms have been disrupted (Kramer et al., 1996) in one allele are myasthenic (Sandrock et al., 1997). ARIA was purified from brain tissue, and NRG1 mRNA is highly expressed in the brain (Falls et al., 1993; Meyer and Birchmeier, 1994; Corfas et al., 1995; Gassmann and Lemke, 1997; Eilam et al., 1998). Because neuregulin is expressed in cholinergic neurons throughout the rodent brain (Corfas et al., 1995), investigating $\mathrm{NRG}$ actions on nicotinic AChRs in potential target neurons is obvious. Earlier work in this laboratory has shown that the EGF-like domain of neuregulin 1 (EGF- $\beta 1$ ) can increase the expression of nicotinic AChRs (nAChRs) on neurons dissociated from the rat interpeduncular nucleus (IPN; Wietasch, 1997). In this paper we report effects of NRG1- $\beta 1$ on nAChRs in neurons dissociated from the hippocampus. Recent studies have shown that GABAergic interneurons, identified in hippocampal slices, are extremely sensitive to applied $\mathrm{ACh}$ and nicotine and bind $\alpha$-bungarotoxin (Freedman et al., 1993; Jones and Yakel, 1997; Frazier et al., 1998a,b; Rory McQuiston and Madison, 1999). We have found the same pattern of sensitivity in cultured hippocampal interneurons. Evidence is presented that neuregulin increases the number of $\mathrm{nACh}$ receptors on these cells and also the number of $\mathrm{nACh}$ receptors on nerve terminals that innervate them. 


\section{MATERIALS AND METHODS}

Culture of hippocampal neurons. Young (3- to 5-d-old) male Sprague Dawley rats were used for all experiments. Housing and treatment of all animals were in accordance with institutional guidelines. Animals were decapitated, and their brains were rapidly removed and placed in cold dissection medium (DM) containing: (in mM) $90 \mathrm{Na}_{2} \mathrm{SO}_{4}, 30 \mathrm{~K}_{2} \mathrm{SO}_{4}, 5.8$ $\mathrm{MgCl}_{2}, 0.25 \mathrm{CaCl}_{2}$, and 1 HEPES. Hippocampal tissue from both hemispheres was gently removed and cut into small pieces. The tissue was digested for $30 \mathrm{~min}$ at $37^{\circ} \mathrm{C}$ in DM solution containing $10 \mathrm{mM} \mathrm{Mg}^{2+}$, $1 \mathrm{~mm}$ kynurenic acid, and $20 \mathrm{U} / \mathrm{ml}$ papain (Worthington Biochemicals, Freehold, NJ). After digestion, the tissue was washed and triturated with fire-polished Pasteur pipettes.

Neurons were purified by centrifugation through a discontinuous density gradient similar to that described by Brewer (1997). Briefly, cells released by trituration were applied to the top of a gradient of Optiprep (Life Technologies, Inc., Gaithersburg, MD; catalog \#1030061) in a 15 $\mathrm{ml}$ centrifuge tube. The gradient was made in four $1 \mathrm{ml}$ steps of density at $0.406,0.29,0.232$, and $0.174 \mathrm{mg} / \mathrm{ml}$ (initial density, $1.32 \mathrm{gm} / \mathrm{ml}$ ) in serum free growth medium (GM) made up of DMEM, $1 \times$ B27, $1 \mathrm{mM}$ sodium pyruvate, $2 \mathrm{mM} \mathrm{L}$-glutamine, $50 \mathrm{U}$ of penicillin, and $50 \mu \mathrm{g} / \mathrm{ml}$ streptomycin. After centrifugation at $1900 \mathrm{rpm}$ for $15 \mathrm{~min}$ at room temperature, neuron-enriched fractions were collected, diluted into $5 \mathrm{ml}$ of serum-free GM, and centrifuged again for $5 \mathrm{~min}$ at $1000 \mathrm{rpm}$ to remove the Optiprep. Cell pellets were resuspended in GM containing $4 \%$ fetal calf serum. For electrophysiological experiments, cells were plated on glass coverslips (Bellco Glass Inc.) at a density of 25,000 to $\sim 40,000$ cells $/ \mathrm{cm}^{2}$. For autoradiography and immunohistochemistry, cells were plated in chambers on a four-well glass slide (Nalge Nunc International). For receptor binding experiments, cells were plated in 48 -well plates at a density of $\sim 200,000 \mathrm{cells} / \mathrm{cm}^{2}$. Coverslips and dishes were coated with $0.1 \mathrm{mg} / \mathrm{ml}$ poly-D-lysine and $0.025 \mathrm{mg} / \mathrm{ml}$ laminin. Cells were maintained at $37^{\circ} \mathrm{C}$ in a $5 \% \mathrm{CO}_{2}$ incubator. After $5 \mathrm{~d}$ in culture, medium was changed to a low-serum $(0.5 \%) \mathrm{GM}$ in the absence or presence of NRG1- $\beta 1$. Hippocampal neurons were studied after 2-4 d of treatment with NRG1- $\beta 1$.

Electrophysiology. Whole-cell patch-clamp recording was performed at the cell soma of the cultured hippocampal neurons. Currents induced by different agonists were recorded from neurons using the standard patchclamp technique. The signals were filtered at $2 \mathrm{kHz}$ using an Axopatch 200B amplifier (Axon Instruments) and directly sampled using pCLAMP7 software (Axon Instruments). Cells were superfused at a rate of $2 \mathrm{ml} / \mathrm{min}$ with an external bath solution containing (in $\mathrm{mM}$ ): 125 $\mathrm{NaCl}, 26 \mathrm{NaHCO}_{3}, 1.25 \mathrm{NaH}_{2} \mathrm{PO}_{4}, 2.5 \mathrm{KCl}, 1 \mathrm{MgCl}_{2}, 2 \mathrm{CaCl}_{2}$, and 25 glucose saturated with $95 \% \mathrm{O}_{2}$ and $5 \% \mathrm{CO}_{2}$. Patch electrodes were made from glass pipettes (VWR Micropipets; catalog \#53432-921) and pulled on a electrode puller (Sutter Instrument Co.). The resistance of the pipettes ranged from 3 to $8 \mathrm{M} \Omega$ when filled with an internal solution that consisted of (in mM): $35 \mathrm{CsF}, 100 \mathrm{CsCl}, 10$ EGTA, and $10 \mathrm{HEPES}$, adjusted to $\mathrm{pH} 7.3$ with $\mathrm{CsOH}$. An ATP-regenerating system $(20 \mathrm{~mm}$ phosphocreatine and $5 \mathrm{~mm}$ ATP Tris salt) was included in the internal recording solution. The holding potential was $-70 \mathrm{mV}$. No series resistance compensation or leak subtraction was performed.

All experiments were performed at room temperature and performed in the absence of TTX unless stated otherwise. The peak amplitudes of ACh-evoked PSCs were measured using Mini Analysis software (Synaptosoft Inc.). To estimate PSC amplitude, when the PSC occurred during the falling phase of a preceding synaptic current, the baseline was estimated by extrapolating the decay of the first peak at the location of the second peak, using a first-order exponential function. Then the peak amplitude was calculated by taking the amplitude at the second peak minus the extrapolated baseline. Statistic significance was evaluated using two-tailed, unpaired $t$ test.

Agonist and antagonist application. Drugs were applied through a modified $U$ tube positioned above the cells within a distance of $60-80 \mu \mathrm{m}$ from the surface of the test neuron (Alkondon and Albuquerque, 1993; Alkondon et al., 1999). An elliptical $\sim 100 \mu \mathrm{m}$ hole was made on the bottom of a glass $U$ tube. The in-flow rate was $0.25 \mathrm{ml} / \mathrm{min}$, and the out-flow rate was $0.5 \mathrm{ml} / \mathrm{min}$. The direction of fluid flow in and out of the $\mathrm{U}$ tube hole was controlled by computer-driven valves. This system allowed rapid application of the agonist without leakage, which is crucial for receptors such as the $\mathrm{nAChR}$, which desensitize rapidly and at a low ACh concentration. Antagonists were applied via the external bathing physiological solution and were also included with the agonist in the $U$ tube system. Inputs to the $\mathrm{U}$ tube were controlled by manual valves.

${ }^{125}$ I- $\alpha$-bungarotoxin binding. To measure specific binding, hippocampal neurons were plated in 48-well plates and cultured for $5 \mathrm{~d}$ as described above. Cells were then treated with $5 \mathrm{~nm}$ NRG1- $\beta 1$ for $3 \mathrm{~d}$. After treatment, all $\mathrm{nAChRs}$ were blocked with unlabeled $\alpha$-bungarotoxin $(\alpha$-BTX; $0.1 \mu \mathrm{M})$ for $1 \mathrm{hr}$ at $37^{\circ} \mathrm{C}$. To measure the incorporation of new receptors into the surface membrane (a measure of the rate of receptor synthesis), plates were washed, and fresh medium containing $1 \mathrm{~nm}$ ${ }^{125} \mathrm{I}$-BTX (specific activity, $2000 \mathrm{Ci} / \mathrm{mmol}$; Amersham Pharmacia Biotech, Arlington Heights, IL) was added. Plates were returned to the incubator for $5 \mathrm{hr}$ at $37^{\circ} \mathrm{C}$. The cells were washed and solubilized, and radioactivity was counted in a gamma counter. Nonspecific binding of ${ }^{125} \mathrm{I}$-BTX was measured in the presence of $1 \mu \mathrm{M}$ unlabeled bungarotoxin. Each sample was assayed in triplicate. Results are presented as mean \pm SEM. Statistical significance was determined by Student's $t$ test.

For autoradiography, cells were cultured on glass slides as described above. After treatment with NRG1- $\beta 1$ for $2 \mathrm{~d}$, cells were washed twice with DMEM and incubated for $1 \mathrm{hr}$ at $37^{\circ} \mathrm{C}$ in binding buffer containing $1 \mathrm{nM}{ }^{125} \mathrm{I}-\mathrm{BTX}$. Nonspecific background was determined by adding $1 \mu \mathrm{M}$ unlabeled $\alpha$-BTX in the medium. After incubation, cells were washed with HBSS and $0.2 \%$ BSA three times for 5 min each. Cells were fixed with $3 \%$ glutaraldehyde at room temperature for $25 \mathrm{~min}$ and then washed three times with HBSS and $0.2 \%$ BSA for 5 min each. Cells were dried at $4^{\circ} \mathrm{C}$ overnight and then subjected to emulsion autoradiography (NTB-3; Eastman Kodak, Rochester, NY; diluted 1:1 with water). Slides were then air-dried again and stored in the dark for $2 \mathrm{~d}$ at $4^{\circ} \mathrm{C}$. Slides were developed according to the manufacturer's instructions (Kodak).

Grains, detected under dark-field illumination, were marked by applying a threshold criterion and then counted by hand. Grain densities were estimated using MetaMorph Imaging System software (Universal Imaging Corp.). Cell areas were calculated after outlining cell bodies and major neurites. Background was estimated by counting grains over the same area displaced to a nearby cell-free locus. Forty-five neurons from control and NRG1- $\beta 1$-treated groups were randomly chosen for analysis. Results are presented as mean \pm SEM. Statistical significance was determined by Student's $t$ test.

Immunohistochemistry. Hippocampal neurons were prepared as described above. Cells were fixed with $4 \%$ paraformdehyde for $30 \mathrm{~min}$ at room temperature and preblocked and permeablized by incubation in $5 \%$ normal goat serum with $0.2 \%$ Triton X-100 in PBS for 60 min. Cells were incubated in the same solution containing a primary antibody to GABA (1:5000, rabbit polyclonal antibody; Sigma, St. Louis, MO) and an AChR $\alpha 7$ subunit (1:2000, monoclonal antibody; Sigma) overnight at $4^{\circ} \mathrm{C}$. Slides were rinsed in PBS and incubated for $1 \mathrm{hr}$ with an FITCconjugated goat anti-rabbit antibody (1:200) and a Cy3-conjugated goat anti-mouse IgG secondary antibody (1:500; Jackson ImmunoResearch, West Grove, PA). Cells were then rinsed in PBS, mounted on slides, and visualized by fluorescence microscopy.

Reagents. Recombinant NRG1- $\beta_{1}$ EGF-like domain was from R \& D Systems (Minneapolis, MN). ACh, $\alpha$-BTX, TTX, phosphocreatine, ATP Tris and 6-cyano-7-nitroquinoxaline-2,3-(1H,4H)-dione (CNQX) were purchased from Sigma. D-APV, GABA, bicuculline methochloride, and methyllycaconitine citrate (MLA) were obtained from Tocris. All drugs and solutions were made fresh from drug stock solutions and dissolved in an external bath solution.

\section{RESULTS}

ACh-evoked currents in cultured hippocampal neurons

Cells were dissociated from hippocampi of 5-d-old rats, and a neuron-enriched cell suspension was obtained by centrifugation through a nonionic iodixanol gradient. One week after plating, large neurons $(\geq 20 \mu \mathrm{M}$ across; Fig. $1 A-C)$ and small neurons $(<20 \mu \mathrm{M}$ across; Fig. $1 D)$ were present. Large neurons were fusiform, triangular (pyramidal), or multipolar shaped (Fig. 1). Counts of cells in randomly selected fields showed that small nerve cells outnumbered large ones by a ratio of $\sim 10: 1$.

Rapid application of $3 \mathrm{~mm}$ ACh to large neurons from a U tube positioned 60-80 $\mu \mathrm{m}$ away resulted in a large inward current that peaked in $\sim 10 \mathrm{msec}$ and decayed in $20-30 \mathrm{msec}$ (Fig. 2A). The rapid decay occurred despite persistent $\mathrm{ACh}$ application, so it is likely attributable to receptor desensitizations. In a series of 97 large neurons, fast, transient currents were observed in 67 (69\%). At a holding potential of $-70 \mathrm{mV}$, the peak current was $1.38 \pm$ 

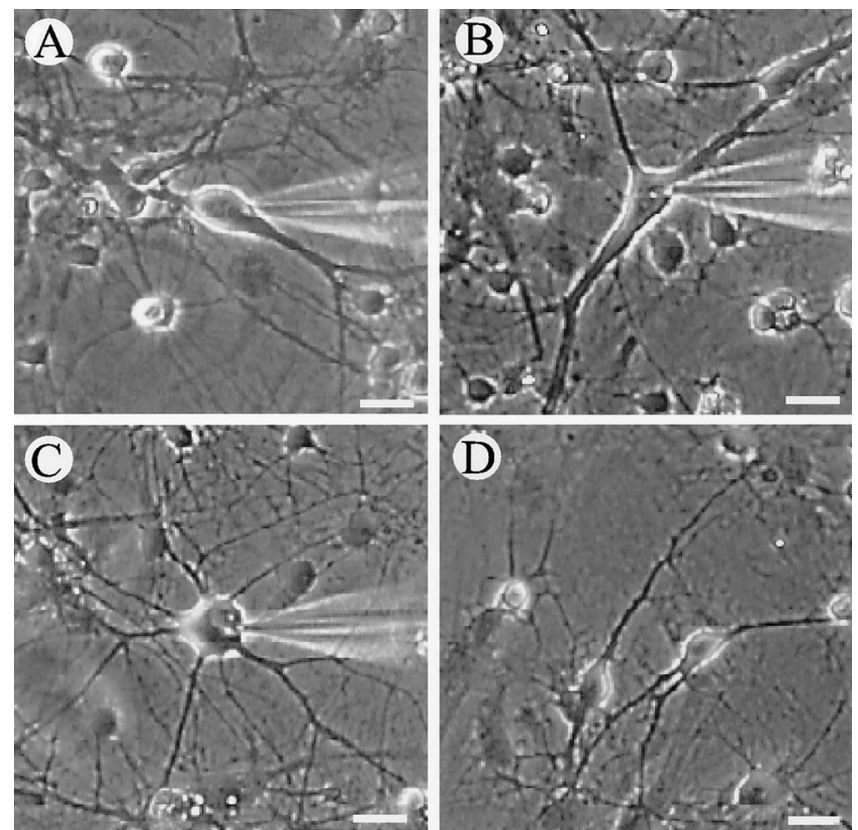

Figure 1. Hippocampal neurons in culture. Neurons were dissociated from $\mathrm{P} 5$ rat hippocampus and maintained in vitro for 7-9 d. $A-C$, Three different classes of large neurons: fusiform $(A)$, triangular $(B)$, and multipolar $(C)$. $D$, Example of small neurons. Scale bar, $20 \mu \mathrm{m}$.

A
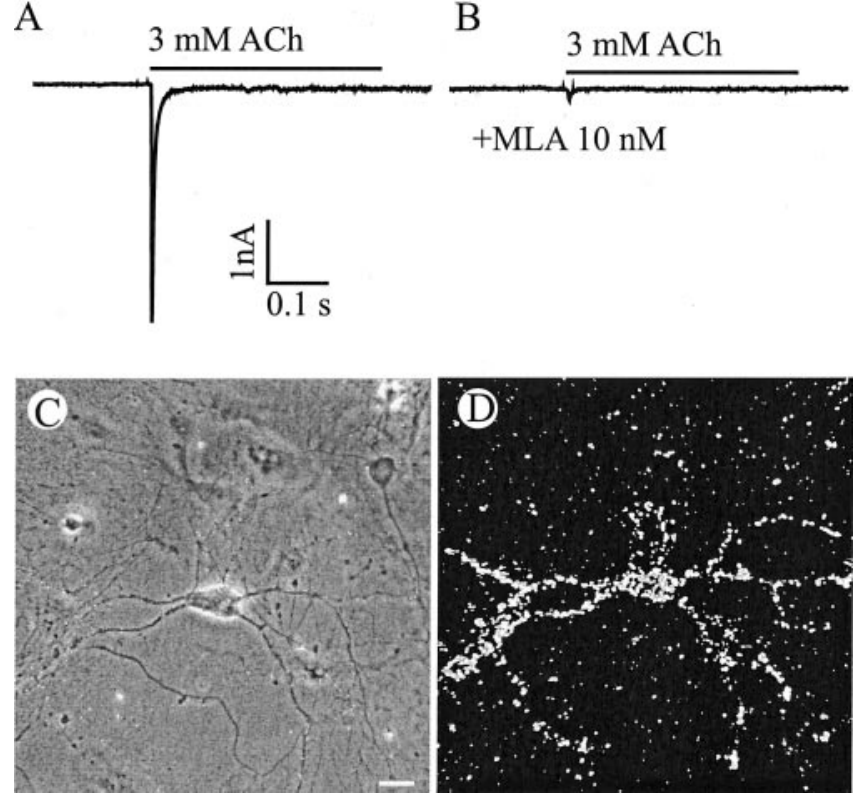

Figure 2. $\alpha 7$-containing nicotinic $\mathrm{ACh}$ receptors. $A$, Fast inward current induced by rapid application of $3 \mathrm{~mm}$ ACh. The application duration is indicated by the bar. B, The current is blocked by MLA, a specific antagonist of $\alpha 7 \mathrm{nAChRs}$. Holding potential, $-70 \mathrm{mV}$. C, $D$, Another neuron shown in phase contrast $(C)$ and dark field $(D)$ after labeling with ${ }^{125}$ I-BTX, which binds specifically to $\alpha 7$ AchRs. ${ }^{125}$ I-BTX heavily labeled both the somata and the dendrites. Scale bar, $20 \mu \mathrm{m}$.

$0.14 \mathrm{nA}(n=81)$. The fast current was seen in all types (shapes) of large neurons. In some cells, the initial inward current was followed by a shower of brief, small inward currents or sharp spikes. Such showers probably reflect transmitter release from presynaptic boutons and will be discussed below (see Fig. 7).

Superfusion with $10 \mathrm{~nm}$ MLA, a selective and potent antago-
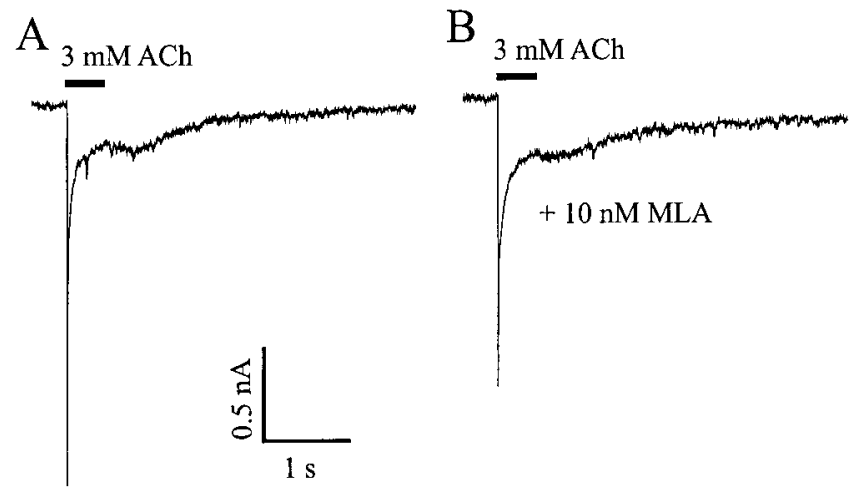

Figure 3. Slow ACh current. ACh (3 mM) was applied at the time indicated by the bar. $A, 3 \mathrm{~mm}$ ACh induced a biphasic response, with the initial fast decay followed by a more slowly decaying current. Holding potential, $-70 \mathrm{mV}$. $B$, The slow component was not blocked by $10 \mathrm{~nm}$ MLA.

nist of $\alpha 7$ subunit-containing nicotinic receptors (Ward et al., 1990), completely blocked the transient ACh-evoked currents (Fig. 2B). Further evidence for $\alpha 7$-containing receptors in large neurons was obtained by autoradiography after exposure to ${ }^{125} \mathrm{I}$ BTX, a snake toxin that binds with high affinity to $\alpha 7$ subunitcontaining nAChRs (Couturier et al., 1990; Seguela et al., 1993). Of 58 large neurons identified, $38(65 \%)$ were labeled by ${ }^{125} \mathrm{I}-$ BTX (Fig. 2C,D). ${ }^{125}$ I-BTX-positive cells represented $<10 \%$ of all neurons (small plus large) present.

In $\sim 16.5 \%$ (16 of 97) of the large neurons, the $\mathrm{ACh}$ response was biphasic, with the initial fast phase followed by a slowly rising current that lasted for $>1 \mathrm{sec}$ (Fig. 3). MLA did not block this late, slow component, suggesting that non- $\alpha 7$-containing nAChRs were also present on these cells. The remaining large neurons (14.5\%) did not respond to ACh at all.

ACh currents were only rarely detected in the smaller neurons, and when present, they were $<0.2 \mathrm{nA}$. Small cells were judged to be neurons because they extended two or more fine processes from their cell bodies, because they received synaptic input as judged by the appearance of discrete PSCs, and because inward currents could be evoked when the membrane was depolarized under voltage-clamp conditions. All data presented below were collected from the relatively large-diameter neurons.

\section{Large neurons that express $\alpha 7 \mathrm{nAChRs}$ are probably GABAergic}

To determine whether the ACh-sensitive neurons in our cultures contain GABA, permeablized cells were labeled with an antibody raised against GABA. We analyzed only the fields that included at least one large neuron. Of 42 large neurons identified, 27 (64\%) were intensely labeled. This is essentially the same as the percentage of large neurons that exhibited transient ACh currents $(69 \%)$. There were 158 small neurons in the same fields of view. Only $8(5 \%)$ were labeled with the anti-GABA antibody. Because less than half of the randomly selected fields included large neurons, we estimate that $<10 \%$ of all neurons under our culture condition were GABA-positive.

In some experiments, neurons were double-labeled with antiGABA and anti- $\alpha 7$ ACh subunit antibodies. All (100\%) GABApositive neurons were intensely labeled with the anti- $\alpha 7 \mathrm{AChR}$ antibody (Fig. 4). Some small GABA-negative neurons also stained with the anti- $\alpha 7$ antibody, but the staining was less intense than in the GABA-positive large neurons. Altogether, $~ 30 \%$ of 
Figure 4. Immunohistochemical localization of GABA and $\alpha 7$ expression in cultured hippocampal neurons. $A$, Phase-contrast cells dissociated from $\mathrm{P} 5$ rat hippocampus and cultured for $8 \mathrm{~d}$ in vitro. $B$, Same field as $A$, viewed with FITC optics. The large neuron is labeled (green) with anti-GABA antibodies. The smaller neurons are not labeled. $C$, Same field viewed with rhodamine optics. The large neuron and one small neuron are labeled (red) with an antibody against the $\alpha 7$ subunit. $D$, Anti-GABA and anti- $\alpha 7$ images superimposed. Areas of overlap appear yellow. Note that the $\alpha 7$-expressing small neuron was negative for GABA expression. D, Inset, Enlarged views of boxed area. Synaptic localization of $\alpha 7$ subunits is suggested by the hot spots of $\alpha 7$ subunits on GABAergic neurites.

the small neurons were labeled above background with anti- $\alpha 7$ antibody.

\section{Neuregulins increase $\mathrm{ACh}$-induced peak inward currents and $\alpha 7-B T X$ binding}

Treatment of cells with $5 \mathrm{~nm}$ NRG1- $\beta 1$ for $2 \mathrm{~d}$ increased the response of large neurons to $\mathrm{ACh}$. The peak inward current was increased more than twofold (Fig. 5, 238\%; $p<0.01$ ). The effect of neuregulin was also evident after 3 or $4 \mathrm{~d}$ of treatment (Fig. $5 B)$, but the amount of fold increase was not as great, because there was an increase in ACh sensitivity of untreated cells with time in culture. Treatment of cultures with 5 nM NRG1- $\beta 1$ also increased the percentage of large neurons that responded to ACh from $69 \%$ (67 of 97) to $93 \%$ (64 of 69), suggesting that NRG1- $\beta 1$ increased $\mathrm{nAChR}$ expression in neurons that had few if any nAChRs before treatment. Treatment with $1 \mathrm{~nm}$ NRG1- $\beta 1$ for $2 \mathrm{~d}$ had no significant effect. Our data are limited to the fast, transient ACh currents, because slowly falling ACh currents were rarely observed (see Fig. 3).

Study of ${ }^{125}$ I-BTX binding on cultured neurons confirmed the electrophysiological measurement. Specific binding of ${ }^{125}$ I-BTX was significantly increased after treatment with $5 \mathrm{~nm}$ NRG1- $\beta 1$ for $2 \mathrm{~d}$ (Fig. 6A). An increase in binding was observed after exposure to $1 \mathrm{~nm}$ NRG1- $\beta 1$. The increase was small, but it was statistically significant $(123 \% ; p<0.001)$.

Autoradiography of cultured neurons led to the same conclusion (see Fig. 2). The grain density over individual neurons was significantly increased after treatment with $5 \mathrm{~nm}$ NRG1- $\beta 1$ $(0.36 \pm 0.03$ grains $/ \mu \mathrm{m})$ compared with control neurons $(0.22 \pm$ 0.02 grains $/ \mu \mathrm{m} ; p<0.001$; Fig. $6 B)$. The cells were not permeablized before incubation with ${ }^{125}$ I-BTX, so the number of sites can be taken as a measure of the receptor density on the surface membrane.

\section{Neuregulins enhance presynaptic $\mathrm{ACh}$ action}

In approximately one-third of the neurons tested, ACh-evoked inward currents were followed by a shower of PSCs (Fig. 7). The
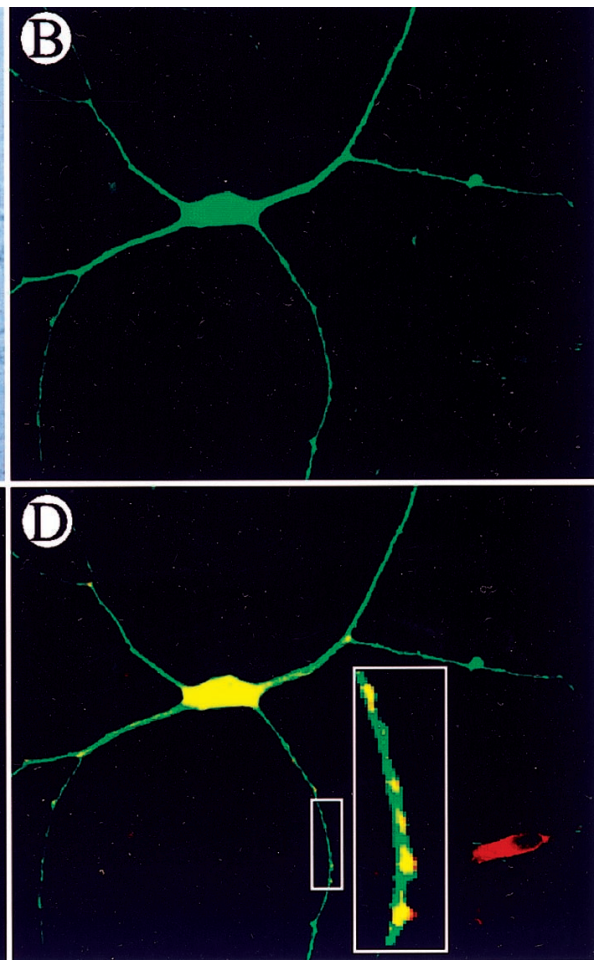

PSCs often were superimposed on a more or less steady depolarization associated with a large increase in baseline fluctuations. The mean amplitude of the PSCs during the ACh-induced barrage was greater than that of the spontaneous PSCs that preceded the ACh pulse, so they probably represent multiquantal synaptic responses. Radcliffe and Dani (1998) observed an increase in the amplitude of synaptic responses after application of nicotine, and paired pulse analysis was consistent with the suggestion that nicotine increased quantal release. In our experiment, the frequency of PSCs was also increased, but we cannot be sure what fraction of the total represented true, single quantal spontaneous PSCs. The showers were blocked completely by low doses of TTX.

In several neurons, sharp spikes followed ACh application in addition to the small PSCs (Fig. $8 A$ ). Such spikes probably reflect action potentials that arise in unclamped receptors of the dendritic tree. As expected, external $\mathrm{Ca}^{2+}$ was required for AChevoked PSCs. Depletion of external $\mathrm{Ca}^{2+}$ abolished ACh-evoked PSCs in both control and NRG1- $\beta 1$-treated groups $(n=11)$.

Coapplication of NMDA and non-NMDA glutamate receptor antagonists, $30 \mu \mathrm{M}$ CNQX plus $50 \mu \mathrm{M}$ APV, reduced or eliminated the ACh triggered PSC shower in 12 of 15 neurons tested (Fig. 8). The effect of the GABA antagonist $10 \mu \mathrm{M}$ bicuculline was not consistent. In some cells, the PSC shower was partially decreased. In a few cells, the PSC shower was enhanced. We conclude that most of the inward PSCs are mediated by glutamate, but GABAergic PSCs are also triggered by ACh application. Bicuculline enhancement of the PSC shower may be attributable to block of GABAergic presynaptic inhibition.

MLA completely abolished the ACh-evoked shower of PSCs in only 4 of 13 neurons tested. This $\alpha 7$-specific antagonist reduced but did not eliminate the PSC shower in 7 of 13 neurons tested. In two cases, the response was not reduced at all. We conclude that non- $\alpha 7$ - as well as $\alpha 7$-containing $\mathrm{ACh}$ receptors are involved.

NRG1- $\beta 1$ treatment more than doubled the percentage of large neurons that exhibited showers of PSCs after application of 


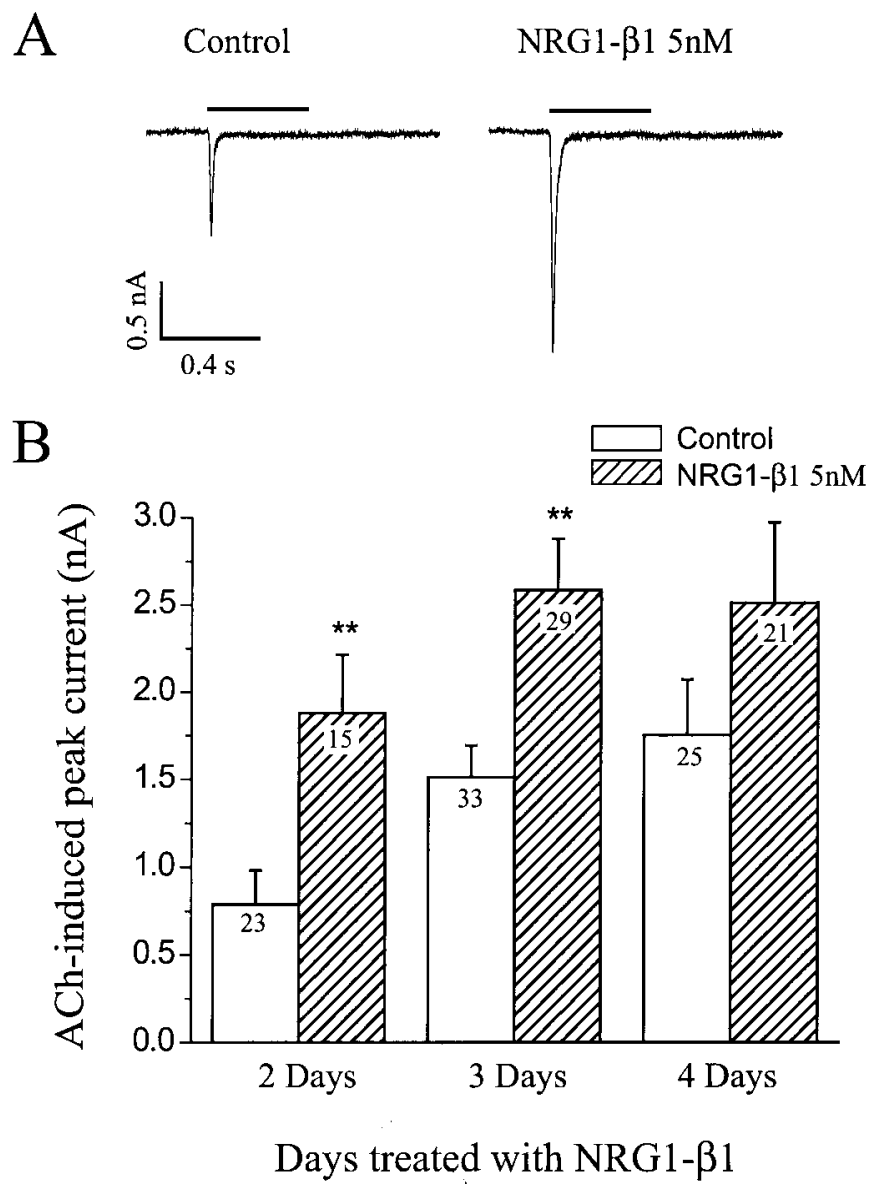

Figure 5. NRG1- $\beta 1$ increases ACh-evoked inward currents. After $5 \mathrm{~d}$ in culture, neurons were treated with $5 \mathrm{nM}$ NRG1- $\beta 1$ for an additional 2-4 d. Representative traces are shown in $A$. Holding potential, $-70 \mathrm{mV}$. $B$, Bar graphs showing mean \pm SEM of ACh-evoked inward currents at the indicated times of treatment. Numbers within bars indicate numbers of neurons assayed. ${ }^{*}$ Significant $(p<0.01)$ differences between means.

ACh (control, 32\%; $n=117$; treated, $74 \% ; n=90)$. The effect was evident after 2, 3, or $4 \mathrm{~d}$ of treatment (Fig. 9).

TTX at $1 \mu \mathrm{M}$ completely blocked ACh-evoked PSCs (Fig. 10), and a significant effect was observed at $2 \mathrm{~nm}$. Thus the AChevoked transmitter release depends on activation of voltagedependent sodium channels and presumably voltage-dependent $\mathrm{Ca}^{2+}$ channels. In any case, it seems clear that $\mathrm{Ca}^{2+}$ influx through ACh channels at or near the synaptic terminal is not sufficient to trigger transmitter release.

NRG1- $\beta 1$ (5 nM) treatment for 2-3 d resulted in an almost twofold increase in the size of ACh-evoked PSCs. The mean amplitudes of PSCs for control and NRG1- $\beta 1$ groups were $173 \pm$ $30 \mathrm{pA}$ (mean \pm SEM from 20 neurons) and $319 \pm 61 \mathrm{pA}$ (mean \pm SEM from 28 neurons), respectively. A typical example is shown in Figure 11.

We found no evidence for a change in postsynaptic receptor sensitivity (quantal size) after NRG1- $\beta 1$ treatment. Glutamate and GABA receptor activity were assayed indirectly by measuring PSCs in the presence of bicuculline and CNQX plus APV, respectively. As shown in Table 1, the amplitudes of PSCs in control and NRG1- $\beta 1$ treatment, detected before application of $\mathrm{ACh}$, were similar in all conditions. It is possible that some of the spontaneous PSCs were in fact triggered by axonal spikes. How-
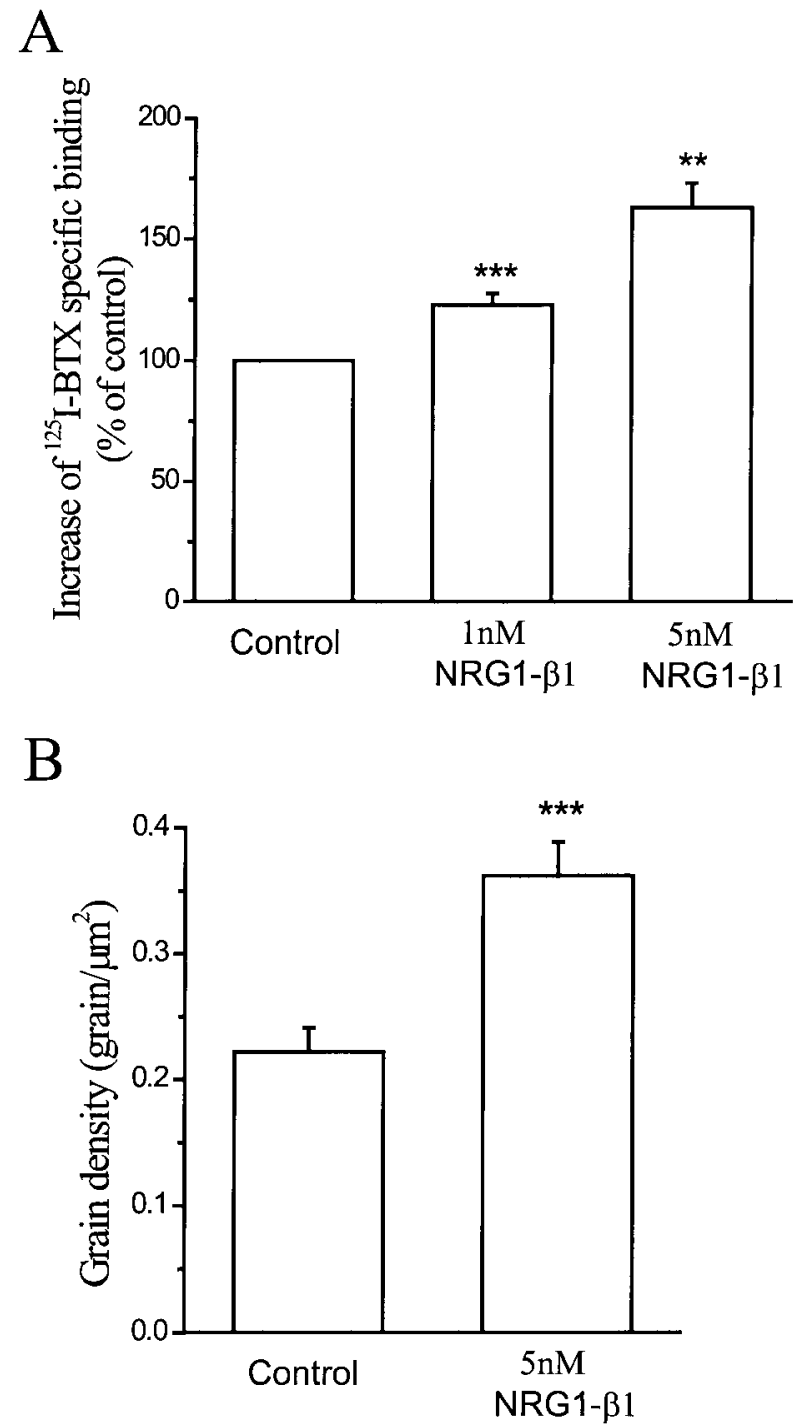

Figure 6. NRG1- $\beta 1$ increases ${ }^{125}$ I-BTX binding. $A$, Bar graphs showing mean \pm SEM of specific ${ }^{125}$ I-BTX binding in cultured hippocampal neurons. After $5 \mathrm{~d}$ in culture, cells were treated with $5 \mathrm{nM}$ NRG1- $\beta 1$ for an additional $3 \mathrm{~d}$ in vitro. Data represent mean values of six $(1 \mathrm{nM}$ NRG1- $\beta 1$ ) and three (5 nM NRG1- $\beta 1$ ) independent experiments. ${ }^{* *} p<$ $0.01 ;{ }^{* *} p<0.001$. $B$, Autoradiography study showing that NRG1- $\beta 1$ increased the ${ }^{125}$ I-BTX grain density over cultured hippocampal neurons. After $5 \mathrm{~d}$ in culture, cells were treated with $5 \mathrm{nM}$ NRG1- $\beta 1$ for an additional $2 \mathrm{~d}$ in vitro. Data show the mean value of 45 neurons that were clearly labeled above background from both control and 5 nM NRG1- $\beta 1$ treated groups. ${ }^{* * *} p<0.001$.

ever, TTX did not alter the mean amplitude of the PSCs (49.5 \pm $6.6 ; n=5$ ).

The frequency of PSCs, averaged over a 2 sec interval after ACh application, was not obviously changed by NRG1- $\beta 1$ treatment. Transient increases in frequency may have been undetected in the 2-sec-long average.

\section{DISCUSSION}

\section{Neuregulins increase $\alpha 7$ responses in GABAergic neurons}

The NRG1- $\beta 1$-induced increase in peak ACh current was accompanied by an increase in the number of ${ }^{125}$ I-BTX binding sites in unpermeablized cells, so the simplest explanation for the physi- 


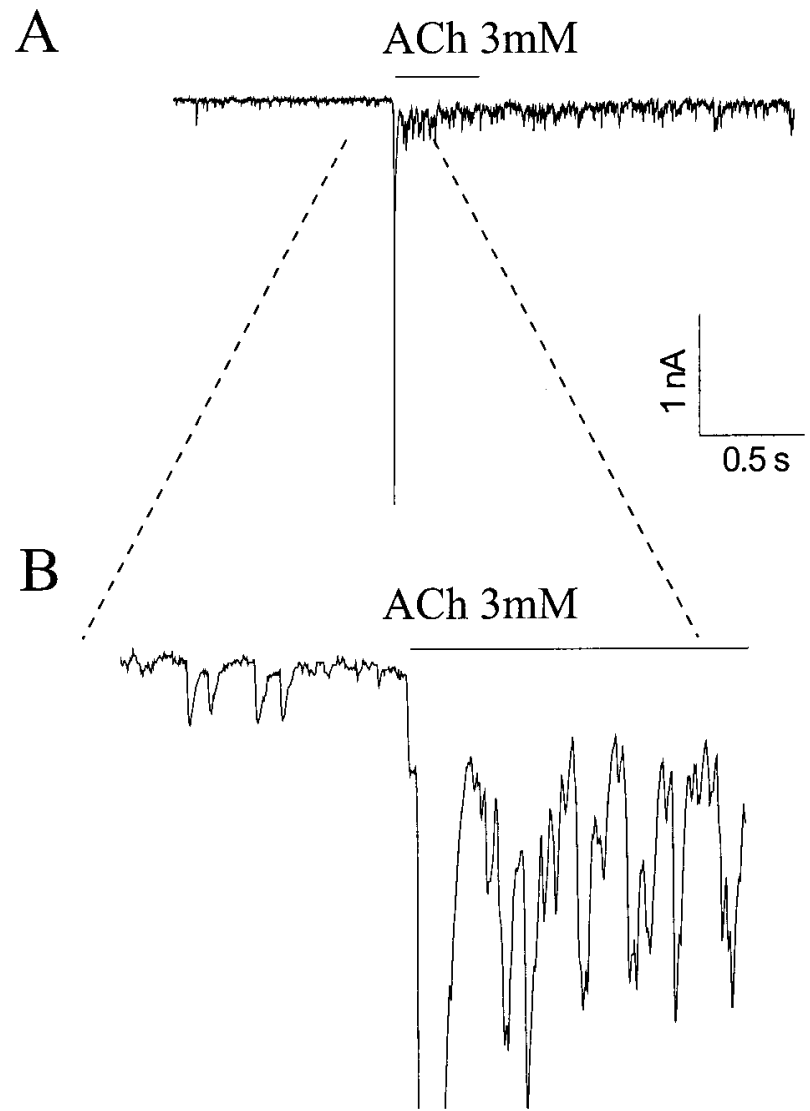

Figure 7. ACh-evoked PSCs from cultured hippocampal neurons. $A$, ACh $(3 \mathrm{~mm})$ was applied via a $\mathrm{U}$ tube at the time indicated by the bar. Holding potential, $-70 \mathrm{mV}$. $B$, Portion of the trace containing the preand post-ACh-evoked PSCs shown in an expanded scale. The time bar refers to $A$.

ological effect is that NRG increased the number of surface membrane $\alpha 7$ AChRs. It remains to be determined whether the increase in receptor number is attributable to an increase in the expression of AChR genes, as is the case at the neuromuscular junction (Harris et al., 1988), or whether it is attributable to insertion of receptors into the surface membrane from a relatively large intracellular pool (Stollberg and Berg, 1987).

Our first experiments suggested that large ACh currents $(>500$ pA) were generated in GABA-containing cells. Only $\sim 10 \%$ of the neurons in our cultures exhibited such large responses after rapid application of $\mathrm{ACh}$, and nearly all of the responsive cells were relatively large. Likewise, $<10 \%$ of the neurons contained GABA-like immunoreactivity, and nearly all of the intensely labeled cells were large. Double-labeling experiments confirmed that $\alpha 7$ AChRs and GABA were expressed in the same neurons.

Similar reasoning suggests that the GABA-containing, AChsensitive cells in vitro correspond to GABAergic interneurons in the intact hippocampus. Only $\sim 10 \%$ of the neurons in the hippocampus are inhibitory interneurons (Olbrich and Braak, 1985; Freund and Buzsaki, 1996). Moreover, GABAergic interneurons in hippocampal slices are extremely sensitive to ACh (Alkondon et al., 1997; Frazier et al., 1998b; McQuiston and Madison, 1999). Relatively rapid $\mathrm{ACh}$ responses in slices are blocked with the $\alpha 7$-specific ligand BTX (Freedman et al., 1993, Frazier et al., 1998b; McQuiston and Madison, 1999). Non- $\alpha 7$ responses were recorded in a minority of the cells in our cultures, and the same

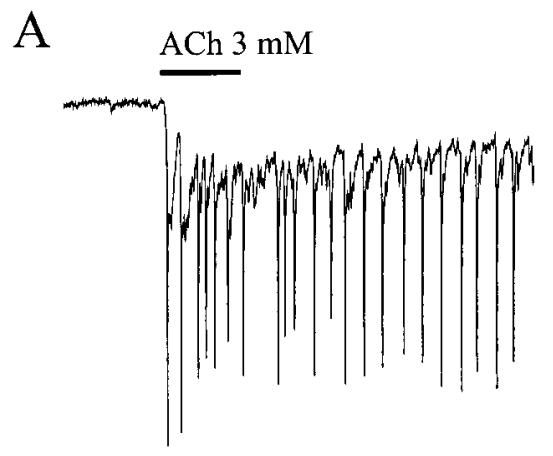

B
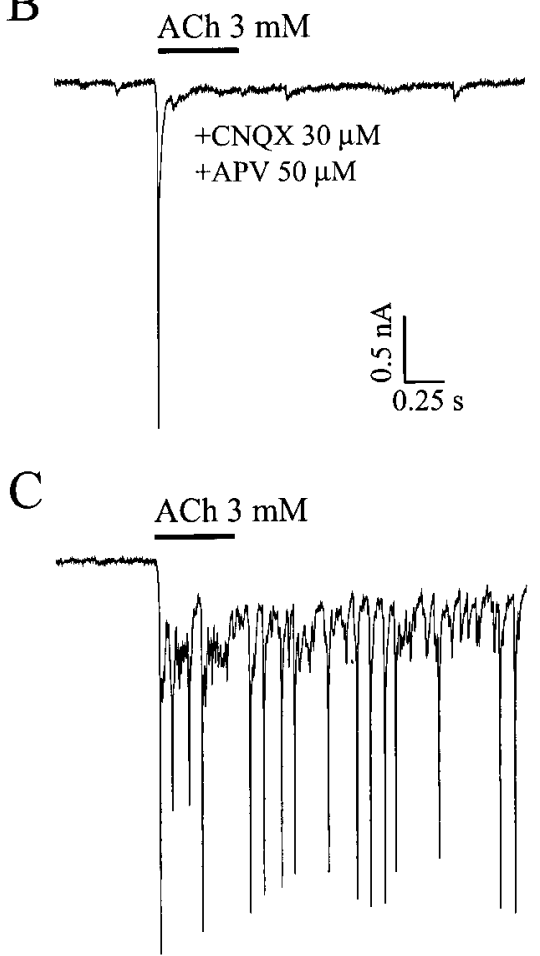

Figure 8. ACh-evoked PSCs are blocked by glutamate receptor antagonists. A, Application of $3 \mathrm{~mm}$ ACh evoked a inward current followed by a burst of PSCs. B, The ACh-evoked PSCs are abolished, but not the inward peak current, in the presence of $30 \mu \mathrm{M} C N Q X$ together with 50 $\mu \mathrm{M}$ APV to block both AMPA and NMDA receptors. $C$, ACh-evoked PSCs recovered after washing out the CNQX and APV. Holding potential, $-70 \mathrm{mV}$.

appears to be the case in slices (McQuiston and Madison, 1999). Finally, there was a marked tendency of the ACh-sensitive neurons in our cultures to fire bursts of action potentials, and this is a characteristic feature of GABAergic interneurons in slices (Frazier et al., 1998a,b). Recognizing the diversity of GABAergic interneurons in the intact hippocampus (Freund and Buzsaki, 1996; Parra et al., 1998; McBain and Fisahn, 2001), we conclude that, as a class, GABAergic neurons are maintained under our culture conditions.

It should be noted that the $\alpha 7$-mediated currents recorded in our cultures were $>10$ times larger than $\alpha 7$ currents in slices, and they rose and fell more rapidly. This is not surprising, considering the high affinity of desensitized $\alpha 7 \mathrm{AChRs}$ for ACh, the speed of desensitization, and the favorable geometry afforded by mono- 


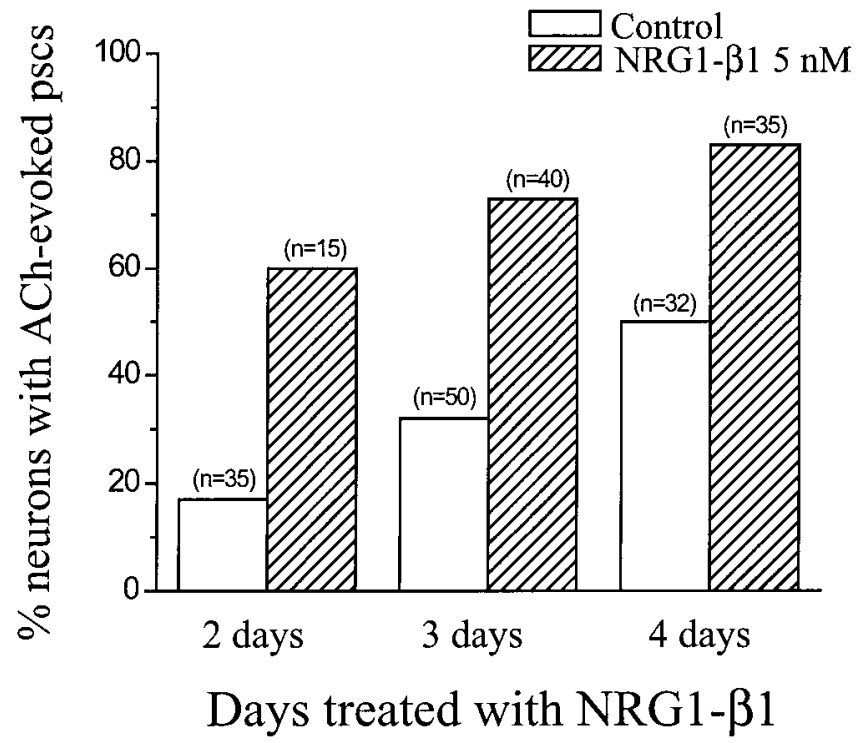

Figure 9. NRG1- $\beta 1$ increased the percentage of neurons that exhibited ACh-evoked PSCs. After $5 \mathrm{~d}$ in culture, cells were treated with $5 \mathrm{~nm}$ NRG1- $\beta 1$ for an additional 2-4 d in vitro. Data show the percentage of neurons that exhibited ACh-evoked PSCs from control and NRG1- $\beta 1$ treated groups. $n$, Number of neurons.
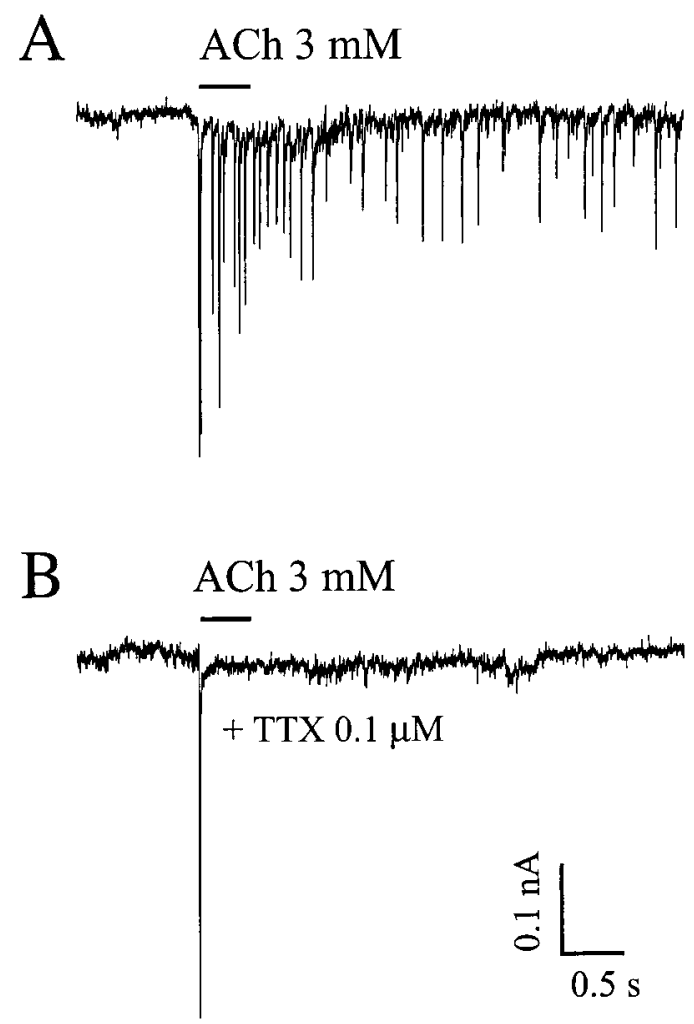

Figure 10. TTX blocks ACh-evoked PSCs in cultured hippocampal neurons. ACh ( $3 \mathrm{~mm})$ was applied via a $\mathrm{U}$ tube at the time indicated by the bar. Traces represent ACh-evoked responses recorded before $(A)$ and after $(B)$ superfusion for $2 \mathrm{~min}$ with TTX. Holding potential, $-70 \mathrm{mV}$.

layer cell cultures allowing the U tube method of ACh application. However, it does point out the importance of avoiding receptor desensitization when assaying $\alpha 7$ responses.

Small-diameter neurons, which made up the great majority of nerve cells in our cultures, may be in vitro correlates of principle neurons in vivo. The cell bodies of dentate granule cells measure only 10-12 $\mu \mathrm{m}$ across. However, the small designation also is a function of time in culture and the culture environment. These cells displayed small ACh currents or none at all, and they were rarely labeled by ${ }^{125} \mathrm{I}-\mathrm{BTX}$. A higher percentage of the small neurons were labeled with the anti- $\alpha 7$ antibody. The cells were permeablized before antibody application, so the antibodies detected AChRs in the intracellular pool as well as the surface membrane. Few, if any, pyramidal neurons in hippocampal slices exhibit fast MLA-sensitive nicotinic ACh responses (Alkondon et al., 1997; Frazier et al., 1998a; McQuiston and Madison, 1999).

\section{Neuregulins enhance presynaptic $\mathrm{ACh}$ responses}

The effect of NRG1- $\beta 1$ on presynaptic nicotinic AChRs results in a large increase in transmitter release that is probably attributable to an increase in the number of quanta released by presynaptic nerve impulses. There was a clear increase in the amplitude of PSCs during the ACh-evoked shower, and there was also an increase in the percentage of neurons that exhibited PSC showers. It is unlikely that postsynaptic modulation of glutamate receptor density or receptor function by neuregulin contributed to the observed increase in PSC amplitude. There was no change in the smallest PSC amplitude recorded in the presence of GABA receptor antagonists or glutamate receptor antagonists. In fact, no showers of PSCs after ACh application were detected in the presence of TTX. Thus, it seems likely that NRG increased the mean quantum content of evoked transmitter release. It will be important to define the stage in excitation-secretion coupling affected by NRG.

The PSC shower was abolished in low- $\mathrm{Ca}^{2+}$ solutions. $\mathrm{Ca}^{2+}$ dependent glutamate release might be activated by $\mathrm{Ca}^{2+}$ entry through $\alpha 7 \mathrm{ACh}$ channels in addition to entry through voltagegated $\mathrm{Ca}^{2+}$ channels. Our data suggest that this is not the case, however, because PSC showers were abolished by $1 \mu \mathrm{M}$ TTX. We conclude that $\mathrm{Ca}^{2+}$ entry through nAChRs at sites of transmitter release is not sufficient.

Our finding that ACh increased transmitter release in heterogeneous hippocampal cultures is not unexpected. Transmitter release after activation of presynaptic nicotinic AChRs has been described in cell cultures, in brain slices, and in synaptosome preparations (McGehee and Role, 1996; Role and Berg, 1996; Albuquerque et al., 1997; Wonnacott, 1997). Our pharmacological experiments indicate that most of the ACh-evoked PSCs are mediated by glutamate. This presents a puzzle, because small neurons, presumably glutamatergic in our cultures, were not very sensitive to ACh. Several explanations can be offered. The small neurons are undoubtedly heterogeneous. It may be that a subpopulation of glutamatergic neurons is more sensitive to ACh than the others. Approximately $30 \%$ of the small neurons were, in fact, labeled by $\alpha 7$ antibodies. Alternatively, it may be that the density of AChRs is higher at nerve terminals than at the perikarya. Finally, a low AChR density, comparable with that present in the somal membrane, might suffice to depolarize small nerve terminals. In any case, it will be important to test, more directly, the possibility that NRG upregulates AChRs at nerve terminals within the CNS. We have focused on glutamatergic terminals, but we did note bicuculline-sensitive PSCs, and an effect of ACh on GABA release has been reported in hippocampal slices (Alkondon et al., 1997). 
A

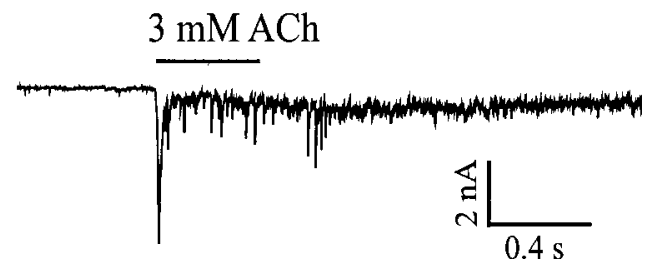

C

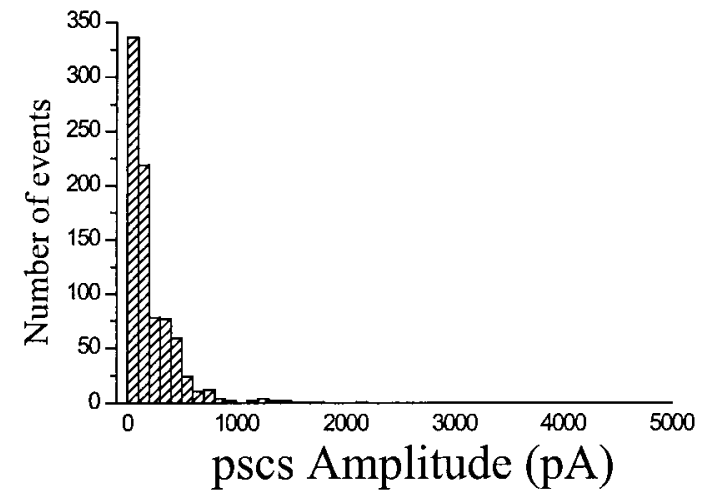

E

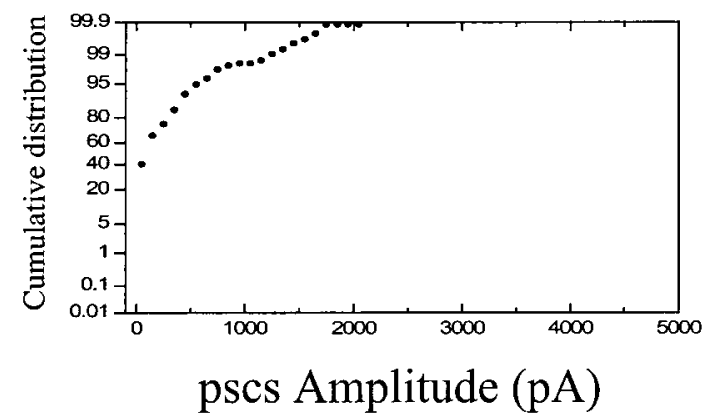

B

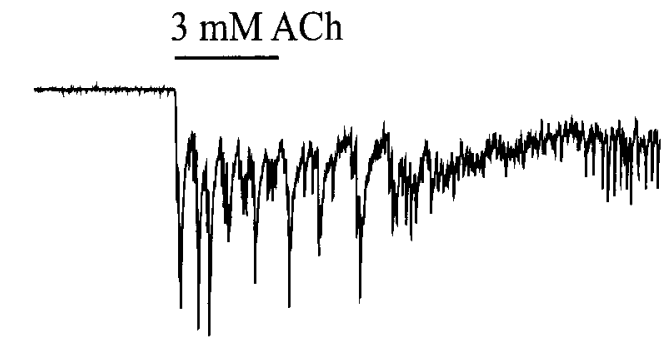

D

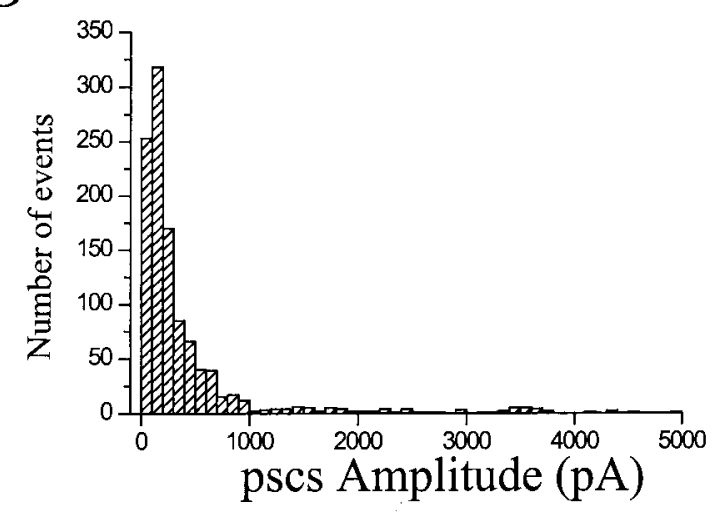

F

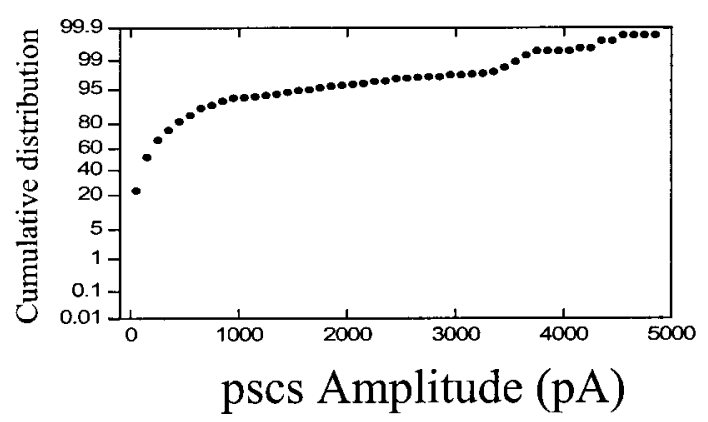

Figure 11. Effects of NRG1- $\beta 1$ on the amplitude of ACh-evoked PSCs in cultured hippocampal neurons. $A$, $B$, Representative current traces showing ACh-evoked responses recorded in control $(A)$ and NRG1- $\beta 1$-treated $(B)$ neurons. $C, D$, Amplitude histograms of PSCs recorded after application of $\mathrm{ACh}$ in control $(C)$ and NRG1- $\beta 1$-treated $(D)$ neurons. Data were collected for $2 \mathrm{sec}$ after each pulse. $E$, $F$, Cumulative distribution of PSC amplitudes in control $(E)$ and NRG1- $\beta 1$-treated $(F)$ cultures. Using the Kolmogorov-Smirnov test (Mini Analysis software; Synaptosoft Inc.), significant differences were observed between control and NRG1- $\beta 1$-treated groups. Holding potential, $-70 \mathrm{mV}$.

Table 1. Spontaneous PSCS in large hippocampal neurons

\begin{tabular}{lllcr} 
& \multicolumn{1}{c}{$\begin{array}{l}\text { Amplitude of PSCS } \\
(\mathrm{pA} ; \text { mean } \pm \text { SEM })\end{array}$} & $\begin{array}{c}\text { No. of PSCS/sec } \\
(\text { mean } \pm \text { SEM) }\end{array}$ & $\begin{array}{r}\text { No. of } \\
\text { neurons }\end{array}$ \\
\hline No antagonist & Untreated & $40.6 \pm 7.2$ & $7.6 \pm 1.8$ & 9 \\
& NRG1- $\beta 1,5 \mathrm{nM}$ & $45.5 \pm 6.5$ & $9.9 \pm 3.1$ & 15 \\
CNQX + APV & Untreated & $32.9 \pm 12.4$ & $2.2 \pm 0.9$ & 4 \\
& NRG1- $\beta 1,5 \mathrm{nM}$ & $29.5 \pm 8.1$ & $4.4 \pm 2.0$ & 11 \\
Bicuculline & Untreated & $44.4 \pm 6.0$ & $13.5 \pm 3.1$ & 6 \\
& NRG1- $\beta 1,5 \mathrm{nM}$ & $48.9 \pm 11.5$ & $9.8 \pm 4.1$ & 5
\end{tabular}

Neurons were dissociated from P5 rat hippocampus and cultured for 7-9 d. After recording the control responses (no antagonist), neurons were superfused with CNQX plus APV or with bicuculine containing extracellular solution. The amplitude of PSCS was recorded for $2 \mathrm{sec}$. Holding potential, $-70 \mathrm{mV}$. 


\section{Neuregulins and their receptors}

The effect of NRG1- $\beta 1$ was measured after exposure to a concentration of $5 \mathrm{nM}$. A small but significant effect on ${ }^{125} \mathrm{I}-\mathrm{BTX}$ binding was observed after exposure to $1.0 \mathrm{~nm}$. Complete doseresponse curves must be constructed to determine the $\mathrm{ED}_{50}$ and the maximal response, but it is already clear that the effect of $\beta 1$ $\mathrm{NRG}$ on AChRs in hippocampal neurons is less potent than its effect on muscle AChRs. In muscle the half-maximal effective dose is 20-50 pM (Falls et al., 1993), a dose that is comparable with that observed in studies of Schwann cell proliferation (Dong et al., 1995; Goodearl et al., 1995) and in binding to breast cancer cells (Holmes et al., 1992). Different potentcies of NRGs on muscle and nerve cells may reflect different combinations of ErbB receptors. At the neuromuscular junction, erbB2 and erbB4 are localized in the depths of the secondary folds of the postsynaptic muscle membrane. ErbB3 is most concentrated in the overlying Schwann cell (Trinidad et al., 2000). NRG could act directly on the ErbB4 receptors of the large GABAergic interneurons, because ErbB4 has recently been identified in hippocampal inhibitory interneurons (Garcia et al., 2000; Huang et al., 2000). But other erbBs have not been sought.

It is also possible that other NRG isoforms may be more potent. Products of the NRG2 and NRG3 genes are expressed in the hippocampus (Carraway et al., 1997; Zhang et al., 1997), but they have not yet been assayed. Moreover, adjacent parts of the NRG molecule may alter potency of the EGF-L domain within a given subclass.

In IPN neurons, a twofold effect on ACh-induced currents was observed after treatment with $100 \mathrm{pm}$ neuregulin. In this case, the EGF-like $\beta 1$ domain was added in the presence of agents that increased cAMP (Wietasch, 1997). Neuregulins modulate nicotinic AChRs on sympathetic neurons. Media collected from cells transfected with a type II $\beta 1-\mathrm{NRG}$ neuregulin isoform that contained a cysteine-rich domain (in place of the Ig-like domain) $\mathrm{N}$-terminal to the EGF-like domain stimulated the synthesis of AChRs approximately twofold, whereas type $1 \beta 1-\mathrm{NRG}$ did not (Yang et al., 1998). However, it is not clear what part of the type II NRG was recovered in the cell-conditioned medium, because recent studies indicate that the cysteine-rich domain is intracellular. Interestingly, in the study of IPN neurons, no effect on ACh-induced currents was observed after application of the fulllength extracellular domain of NRG1 (Wietasch, 1997). We do not know whether the differences reported in this study and that of Yang et al. (1998) are attributable to differences in potency or to differences in efficacy between $\beta 1$ isoforms.

\section{Physiological implications}

Upregulation of nicotinic receptors might increase inhibition in the hippocampus by enhancing the ability of septal cholinergic afferents to activate GABAergic interneurons. Early electron microscopic autoradiography showed that $\alpha$-BTX binding sites are located precisely at synaptic complexes (Hunt and Schmidt, 1978). Those authors suggested that the postsynaptic partners might be dendrites of interneurons in the stratum oriens. Also, cholinergic terminals have been identified on somata and dendrites of relatively large GABAergic neurons in the stratum radiatum of the CA3 region (Frotscher, 1989), as well as dentate gyrus (Dougherty and Milner, 1999) of the hippocampus. A synaptic localization of $\alpha 7$ subunits is suggested in our experiments. Figure 4 shows that hot spots of rhodamine-BTX are located on GABA-containing neurites (Fig. 4, inset). Most directly, EPSCs have been recorded in hippocampal interneurons (striatum radiatum of CA1) that are reduced significantly by BTX and MLA (Frazier et al., 1998b; but see McQuiston and Madison, 1998).

Neuregulin might also enhance GABAergic action by enhancing the excitatory drive provided by retrograde connections from intrinsic pyramidal neurons or anterograde connections from the cortex. Additional experiments with higher-resolution probes are needed to more precisely localize presynaptic AChRs. It should be noted that no anatomical or physiological evidence has been presented for axo-axonic synapses on interneuron terminals in the hippocampus.

Further studies are important because GABAergic interneurons exert a profound influence on hippocampal circuits (Freund and Buzsaki, 1996; Jones and Yakel, 1999; McBain and Fisahn, 2001). Changes in inhibitory drive might affect activitydependent changes in synaptic efficacy. Interestingly, a recent report indicates that $\beta 1-\mathrm{NRG}$ inhibits long-term potentiation in hippocampal slices (Huang et al., 2000). In this case, the effect was observed within a few minutes of application.

\section{REFERENCES}

Albuquerque EX, Alkondon M, Pereira EF, Castro NG, Schrattenholz A, Barbosa CT, Bonfante-Cabarcas R, Aracava Y, Eisenberg HM, Maelicke A (1997) Properties of neuronal nicotinic acetylcholine receptors: pharmacological characterization and modulation of synaptic function. J Pharmacol Exp Ther 280:1117-1136.

Alkondon M, Albuquerque EX (1993) Diversity of nicotinic acetylcholine receptors in rat hippocampal neurons. I. Pharmacological and functional evidence for distinct structural subtypes. J Pharmacol Exp Ther 265:1455-1473.

Alkondon M, Pereira EF, Barbosa CT, Albuquerque EX (1997) Neuronal nicotinic acetylcholine receptor activation modulates gammaaminobutyric acid release from CA1 neurons of rat hippocampal slices. J Pharmacol Exp Ther 283:1396-1411.

Alkondon M, Pereira EF, Eisenberg HM, Albuquerque EX (1999) Choline and selective antagonists identify two subtypes of nicotinic acetylcholine receptors that modulate GABA release from CA1 interneurons in rat hippocampal slices. J Neurosci 19:2693-2705.

Brewer GJ (1997) Isolation and culture of adult rat hippocampal neurons. J Neurosci Methods 71:143-155.

Carraway III KL, Burden SJ (1995) Neuregulins and their receptors. Curr Opin Neurobiol 5:606-612.

Carraway III KL, Weber JL, Unger MJ, Ledesma J, Yu N, Gassmann M, Lai C (1997) Neuregulin-2, a new ligand of ErbB3/ErbB4-receptor tyrosine kinases. Nature 387:512-516.

Corfas G, Rosen KM, Aratake H, Krauss R, Fischbach GD (1995) Differential expression of ARIA isoforms in the rat brain. Neuron 14:103-115.

Couturier S, Bertrand D, Matter JM, Hernandez MC, Bertrand S, Millar N, Valera S, Barkas T, Ballivet M (1990) A neuronal nicotinic acetylcholine receptor subunit (alpha 7) is developmentally regulated and forms a homo-oligomeric channel blocked by alpha-BTX. Neuron $5: 847-856$

Dong Z, Brennan A, Liu N, Yarden Y, Lefkowitz G, Mirsky R, Jessen KR (1995) Neu differentiation factor is a neuron-glia signal and regulates survival, proliferation, and maturation of rat Schwann cell precursors. Neuron 15:585-596.

Dougherty KD, Milner TA (1999) Cholinergic septal afferent terminals preferentially contact neuropeptide Y-containing interneurons compared to parvalbumin-containing interneurons in the rat dentate gyrus. J Neurosci 19:10140-10152.

Eilam R, Pinkas-Kramarski R, Ratzkin BJ, Segal M, Yarden Y (1998) Activity-dependent regulation of Neu differentiation factor/neuregulin expression in rat brain. Proc Natl Acad Sci USA 95:1888-1893.

Falls DL, Rosen KM, Corfas G, Lane WS, Fischbach GD (1993) ARIA, a protein that stimulates acetylcholine receptor synthesis, is a member of the neu ligand family. Cell 72:801-815.

Fischbach GD, Rosen KM (1997) ARIA: a neuromuscular junction neuregulin. Annu Rev Neurosci 20:429-458.

Frazier CJ, Rollins YD, Breese CR, Leonard S, Freedman R, Dunwiddie TV (1998a) Acetylcholine activates an alpha-bungarotoxin-sensitive nicotinic current in rat hippocampal interneurons, but not pyramidal cells. J Neurosci 18:1187-1195.

Frazier CJ, Buhler AV, Weiner JL, Dunwiddie TV (1998b) Synaptic potentials mediated via alpha-bungarotoxin-sensitive nicotinic acetylcholine receptors in rat hippocampal interneurons. J Neurosci 18:8228-8235. 
Freedman R, Wetmore C, Stromberg I, Leonard S, Olson L (1993) $\alpha$-bungarotoxin binding to hippocampal interneurons: immunocytochemical characterization and effects on growth factor expression. J Neurosci 13:1965-1975.

Freund TF, Buzsaki G (1996) Interneurons of the hippocampus. Hippocampus 6:347-470.

Frotscher M (1989) Central cholinergic synapses: the septohippocampal system as a model. In: Centrol cholinergic synaptic transmission (Frotscher M, Misgeld U, eds), pp 33-41. Basel: Birkhauser.

Garcia RA, Vasudevan K, Buonanno A (2000) The neuregulin receptor ErbB-4 interacts with PDZ-containing proteins at neuronal synapses. Proc Natl Acad Sci USA 97:3596-3601.

Gassmann M, Lemke G (1997) Neuregulins and neuregulin receptors in neural development. Curr Opin Neurobiol 7:87-92.

Goodearl AD, Davis JB, Mistry K, Minghetti L, Otsu M, Waterfield MD, Stroobant P (1993) Purification of multiple forms of glial growth factor. J Biol Chem 268:18095-18102.

Goodearl AD, Yee AG, Sandrock Jr AW, Corfas G, Fischbach GD (1995) ARIA is concentrated in the synaptic basal lamina of the developing chick neuromuscular junction. J Cell Biol 130:1423-1434.

Harari D, Tzahar E, Romano J, Shelly M, Pierce JH, Andrews GC, Yarden Y (1999) Neuregulin-4: a novel growth factor that acts through the ErbB-4 receptor tyrosine kinase. Oncogene 18:2681-2689.

Harris DA, Falls DL, Dill-Devor RM, Fischbach GD (1988) Acetylcholine receptor-inducing factor from chicken brain increases the level of mRNA encoding the receptor alpha subunit. Proc Natl Acad Sci USA 85:1983-1987.

Holmes WE, Sliwkowski MX, Akita RW, Henzel WJ, Lee J, Park JW, Yansura D, Abadi N, Raab H, Lewis GD (1992) Identification of heregulin, a specific activator of p185erbB2. Science 256:1205-1210.

Huang YZ, Won S, Ali DW, Wang Q, Tanowitz M, Du QS, Pelkey KA, Yang DJ, Xiong WC, Slater MW, Mei L (2000) Regulation of neuregulin signaling by PSD-95 interacting with ErbB4 at CNS synapses. Neuron 26:443-455.

Hunt SP, Schmidt J (1978) The electron microscopic autoradiographic localization of $\alpha$-bungarotoxin binding sites within the central nervous system of the rat. Brain Res 142:152-159.

Jones S, Yakel JL (1997) Functional nicotinic ACh receptors on interneurones in the rat hippocampus. J Physiol (Lond) 504:603-610.

Jones S, Yakel JL (1999) Inhibitory interneurons in hippocampus. Cell Biochem Biophys 31:207-218.

Kramer R, Bucay N, Kane DJ, Martin LE, Tarpley JE, Theill LE (1996) Neuregulins with an Ig-like domain are essential for mouse myocaridal and neuronal development. Proc Natl Acad Sci USA 93:4833-4838.

Lemke G (1996) Neuregulins in development. Mol Cell Neurosci 7:247-262.

Marchionni MA, Goodearl AD, Chen MS, Bermingham-McDonogh O, Kirk C, Hendricks M, Danehy F, Misumi D, Sudhalter J, Kobayashi K, (1993) Glial growth factors are alternatively spliced erbB2 ligands expressed in the nervous system [see comments]. Nature 362:312-318.

McBain CJ, Fisahn A (2001) Interneurons unbound. Nat Rev Neurosci 2:11-23.

McGehee DS, Role LW (1996) Presynaptic ionotropic receptors. Curr Opin Neruobiol 6:342-349.

McQuiston AR, Madison DV (1999) Nicotinic receptor activation excites distinct subtypes of interneurons in the rat hippocampus. J Neurosci 19:2887-2896.
Meyer D, Birchmeier C (1994) Distinct isoforms of neuregulin are expressed in mesenchymal and neuronal cells during mouse development. Proc Natl Acad Sci USA 91:1064-1068.

Meyer D, Yamaai T, Garratt A, Riethmacher-Sonnenberg E, Kane D, Theill LE, Birchmeier C (1997) Isoform-specific expression and function of neuregulin. Development 124:3575-3586.

Olbrich HG, Braak H (1985) Ratio of pyramidal cells versus nonpyramidal cells in sector CA1 of the human Ammon's horn. Anat Embryol 173:105-110.

Parra P, Gulyas AI, Miles R (1998) How many subtypes of inhibitory cells in the hippocampus? Neuron 20:983-993.

Radcliffe KA, Dani JA (1998) Nicotinic stimulation produces multiple forms of increased glutamatergic synaptic transmission. J Neurosci 18:7075-7083.

Role LW, Berg DK (1996) Nicotinic receptors in the development and modulation of CNS synapses. Neuron 16:1077-1085.

Rory McQuiston A, Madison DV (1999) Nicotinic receptor activation excites distinct subtypes of interneurons in the rat hippocampus. J Neurosci 19:2887-2896.

Sandrock Jr AW, Dryer SE, Rosen KM, Gozani SN, Kramer R, Theill LE, Fischbach GD (1997) Maintenance of acetylcholine receptor number by neuregulins at the neuromuscular junction in vivo. Science 276:599-603.

Seguela P, Wadiche J, Dineley-Miller K, Dani JA, Patrick JW (1993) Molecular cloning, functional properties, and distribution of rat brain alpha 7: a nicotinic cation channel highly permeable to calcium. J Neurosci 13:596-604.

Stollberg J, Berg DK (1987) Neuronal acetylcholine receptors: fate of surface and internal pools in cell culture. J Neurosci 7:1809-1815.

Trinidad JC, Fischbach GD, Cohen JB (2000) The Agrin/MuSK signaling pathway is spatially segregated from the neuregulin/ErbB receptor signaling pathway at the neuromuscular junction. J Neurosci 20:8762-8770.

Usdin TB, Fischbach GD (1986) Purification and characterization of a polypeptide from chick brain that promotes the accumulation of acetylcholine receptors in chick myotubes. J Cell Biol 103:493-507.

Ward JM, Cockcroft VB, Lunt GG, Smillie FS, Wonnacott S (1990) Methyllycaconitine: a selective probe for neuronal alpha-bungarotoxin binding sites. FEBS Lett 270:45-48.

Wen D, Peles E, Cupples R, Suggs SV, Bacus SS, Luo Y, Trail G, Hu S, Silbiger SM, Levy RB, et al (1992) Neu differentiation factor: a transmembrane glycoprotein containing an EGF domain and an immunoglobulin homology unit. Cell 69:559-572.

Wietasch K (1997) Regulation of neuronal nicotinic acetylcholine receptors in the interpeduncular nucleus. PhD thesis, Harvard University.

Wonnacott S (1997) Presynaptic nicotinic ACh receptors. Trends Neurosci 20:92-98.

Yang X, Kuo Y, Devay P, Yu C, Role L (1998) A cysteine-rich isoform of neuregulin controls the level of expression of neuronal nicotinic receptor channels during synaptogenesis. Neuron [Erratum (1998), 20:823] 20:255-270.

Zhang D, Sliwkowski MX, Mark M, Frantz G, Akita R, Sun Y, Hillan K, Crowley C, Brush J, Godowski PJ (1997) Neuregulin-3 (NRG3): a novel neural tissue-enriched protein that binds and activates ErbB4. Proc Natl Acad Sci USA 94:9562-9567.

Zhang D, Frantz G, Godowski PJ (1998) New branches on the neuregulin family tree [news]. Mol Psychiatry 3:112-115. 